\title{
EDUCATIONAL ACTIVITIES FOR OLDER ADULTS DEVELOPMENT IN LITHUANIAN SOCIAL CARE INSTITUTIONS
}

\author{
Irena Zemaitaityte \\ Mykolas Romeris University, Lithuania
}

\begin{abstract}
The article reviews educational activities for older adults in social care institutions. The growing numbers of older people in the society create an imperative to keep reviewing and adapting for the newly emerging needs societal resources in the areas of social security, economics, education, and health care. Recent discussions about the potential of institutional social care to meet societal needs are gaining momentum in Lithuania and the challenge is to offer alternative, equally agreeable, forms of social care as, for example, social care of the adults at their own homes, involvement of non-governmental organisations into the provision of social and educational service provision. However, it is broadly accepted that social care provided for older adults in the social care institutions plays an important role in the provision of social and educational services and will continue to play this role in future.
\end{abstract}

Keywords: educational activities, older adults, social care institutions.

\section{Introduction}

Demographic convergences of the recent decades impact population age structures and result in the ageing of the society in Lithuania. The growing numbers of older people in the society create an imperative to keep reviewing and adapting for the newly emerging needs societal resources in the areas of social security, economics, education, and health care. In 2012 in Lithuanian in social care institutions there lived around 4,5 thousand people older than 60 . Key challenges that face social gerontology and educational acceleration are management and provision of social and educational services in compliance with the older adults' needs as well as supporting conditions for active and healthful ageing.

S. Mikulionienè (2011) views population ageing as a predictable result of demographic evolution of the society. Though in Lithuania this process is often approached through its negative aspects, in S. Mikulioniene's opinion it is „,not only an imminent outcome of demographic transition, but it is also a desirable outcome (population life span gets longer)“ (Mikulionienè, 2011, p. 224). This goal - to ensure longer and complete human life- calls for no objections. Changing population age structure - from the young age dominated society to the society with an equal distribution of different age groups, in S. Mikulioniene's (2011) opinion, is and will continue to stay a challenge to the development of social, economic and cultural life in a society. Because of the scope and of the irreversible character of the phenomenon, population ageing 
critically impacts upon societal needs structures and at the same time challenge social institutions that are designed to meet those needs. In the opinion of V. Lukamskiene and A. Budejiene (2013) ageing society conditions the change in the role of the family as a social institution. The researchers make a proposition that in future the care of older adults might be handed over to social service organisations for the provision of social services. The situation touches upon the issue of social inclusion, when each member of the society is given an opportunity to take an active part in the society's life no individual encounters obstacles in search of an activity meaningful for the society (Gray, 2000). Social inclusion of older adults means enhancing access to educational activities and supporting participation in such activities (Zemaitaityte, 2014).

The paper seeks to discuss the types of educational activities offered to older adults in social care institutions; the ways older people engage themselves with these activities; the challenges that social workers meet in managing and providing these educational activities.

Research is based on national statistical data, the data of the focus group interviews carried out to answer research questions.

\section{Social care institutions for older adults}

2012 was the European year of active ageing and solidarity of generations. In the attempt to match the requirements of older adults and to provide conditions for active and dignified ageing, it attracted greater attention to the provision of social services, educational stimulation, activity organisation and provision. Since the society is ageing and a lifespan is becoming longer it is likely that the need for a continuous care and nursing in future will only grow, and as a consequence the demand for social care institutions will grow as well. Social care institutions are the institutions whose primary goal is to support vital activities of individuals and of social groups and to deal with social problems as they arise in managing the provision of services and secure environment (Zalimiene, 2003). Social services form an integral part of a national welfare and assist society in dealing with social issues. Fast changing social and economic environment, globalisation, economic changes stimulate interest in the most effective service provision. According to Lithuanian Statistics Department (2013) 102 social care institutions were providing social care services in 2012, 4,5 thousand older adults received these services. The majority of the above institutions function within the regulatory supervision of local municipalities; others are public enterprises or private institutions. Stationary care institutions for older adults are the following types: care houses for older people, geared for people, who are in need of permanent nursing and care and for people who because of their old age and deterioration are unable to live on their own at home; independent residences, which are mainly for older people, who are in no need of permanent care and nursing, but may require minor assistance or some 
social services. Stationary care institutions provide the following types of services for older adults: supply of information and consulting, social work, provision of abode, personal health services and arranging of nursing services, leisure and social activities and the like. Older individuals have a choice of moving to a stationary care house with either a long-term or a short-term social care. Short -term social care is an opportunity for an older adult to mix with one's own age group, to establish new social connections, to apply for the leisure and educational activities offered by professionals (Kuzmickienè, 2011). Recent discussions about the potential of institutional social care to meet societal needs are gaining momentum in Lithuania and the challenge is to offer alternative, equally agreeable, forms of social care as, for example, social care of the adults at their own homes, involvement of non-governmental organisations into the provision of social and educational service provision. However, it is acknowledged that social care provided for older adults in the social care institutions plays an important role in the provision of the social and educational services and will continue to play this role in future.

At present the measurement and assessment of the quality of social services to diverse groups of clients in Lithuania are at their initial stage. Pursuing the goals of social service quality in Lithuania, the attempts are made to define and describe the quality of social services and criteria for quality assessment. In other words, currently, the concept of the social service quality is under discussion. This discussion is of extreme importance for social workers, who provide social and educational services for elderly clients, since the occupational quality is associated with the growth of the professional prestige in the society.

\section{Educational activities as leisure activities for older adults}

The Catalogue of Social Services $(2006,2013)$ does not list educational activities as such, but in practice they are organised as sociocultural, educational services, which are defined in the Catalogue as leisure activity planning, provided as a mediational means for avoiding social conflicts (prevention activities), for bridging the social exclusion gap and activating the community. In the process of the provision of these services individuals (families) can communicate with each other, take part in group activities, spend time on one's favourite pastimes. J. Šinkūnienè (2005) describes leisure as time span devoted for dealing with personal requirements, for personal development, accumulation of knowledge, personal growth. Leisure activities are an individual right to make choice by which an individual reveals one's attitude to the value system. In planning educational activities and managing leisure time for older adults it is important to mind the needs of the participants of these activities. J. Kuzmickiene (2011) holds the view that every elderly person has one's favourite activities and makes independent decisions of how much time and energy to spend on them. Some are interested in a single type of activity, others 
spread their time, skills and knowledge over several types of activities: they get involved in work or community organisations, give time to family and social function, show interest in arts, theatre, books, music. J. Miezyte-Tijusiene and L. Bulotaite (2012) observe that though an expanding amount of leisure time should cause satisfaction, this is not always the case. In some cases appropriation of the augmented free time may evoke unpleasant feelings and this causes boredom for older people, a feeling of senselessness. Therefore, educational activities and leisure time organisation are an important aspect of the subjective welfare of older adults. D. Staniuleviciene (2002) states that leisure time can become a source for personal growth, experience, calmness, happiness, self-expression. V. Cernius (2006) remarks that mandatory old age leave at work may cause faster ageing, while older adults who continue their work function have a better quality of life. „The longer older people stay active, occupied, the happier their old age is" (Cernius, 2006, p. 261). J. MiezyteTijusienè, L. Bulotaite (2012) also note that social activity help old people to deal with emotions and this enhances their psychic balance. Social activity also provides the opportunity to contact to other people and receive support.

Lithuania has no profession designated to organise leisure and educational activities, these services are most often provided by social workers, who apart from social work organise and provide sociocultural and educational services. A social worker in one's function of providing leisure and educational activities to older people often acts as an analyst who seeks to identify the inclinations, needs and interests of an elderly person, is aware of the leisure development trends for older people, of typical features of diverse leisure activity types; an organiser, who plans educational activities, prepares and implements activity plans, organises educational and cultural events; an enabler who seeks to interest older people in new leisure and educational activities, encourages active participation; a mediator who assists in establishing social contacts during educational activities; a consultant a social worker who helps to overcome failures, gives attention and empathy; a creator - often social workers themselves work on projects, social programmes to help older adults in selfrealisation (Leliugiene, 2003). M. Spierts (2003) also admits that education is a mandatory part of a sociocultural work, but educational work may be an entirely independent function. It can be oriented towards forming an opinion, acquiring and developing knowledge, augmenting social and cultural skills.

\section{Attitudes of social workers to the organisation of educational activities in social care institutions}

While working on the international lifelong learning project "INNOMEC Innovative Management and Educational Practices in Elderly Centres" in the period 2013-2015 (No. 539829-LLP-1-2013-1-IT-GRUNDTVIG-GMP) project partners: Speha Fresia (coordinate, Italy); Inspire (Austria); EURO Idea 
(Belgium), Mykolas Romeris University (Lithuania); Studi Centro Veneto (Italy); Hrafnista (Iceland) carried out a study of focus groups in the attempt to identify educational activities prepared for the older adults.

In order to reveal distinctive experience obtained by a social worker while working in social service for older people the phenomenological research method was chosen. From the phenomenological point of view experience emerges from the stream of daily life (Van Manen, 2014). Qualitative research intended to approach the world "out there" and to understand, describe and explain phenomena "from the inside“ by analysing experiences of individuals and groups; by reviewing interactions and communications in the making; by studying documents. Data elicited in focus groups was used to provide a window on subjective experience - but this was the least of what this approach enabled achieving (Barbour, 2007). Characteristics of the Lithuanian focus group participants are the following: ten social workers (each focus group participant - women) working in institutions for the elderly; the focus group age ranged from 30 to 45 . The scope of research participants is targeted, i. e. the informants that are able to reflect and reason about the researched phenomenon responsibly were selected. Selection criteria: gerontology work experience in social service for older adults no less than 5 years; professional qualifications of the social work - university-level education.

The data was collected using the focus group interview method in order to answer the raised questions of the research. The data of the research were collected on May of 2014 after focus group meeting at Mykolas Romeris University (Lithuania); interviews were recorded using the dictaphone. Focus group interview lasted $2-2.5$ hours. The researchers obligated themselves to the participants of the research to keep the information related to the concrete social service (institution) informant anonymous. The research was based on the principles of anonymity, voluntarism and goodwill. The social workers were acquainted with the goal of the research and its circumstances, interview questions and the importance of the reflection of their experience. The focus group of the participants comes from Vilnius region. The choice of setting can be considered as limited. The location has an influence on the discussion, and it is important to consider the connotations that a particular location may have for participants (Barbour, 2007)

By analysing a variety of educational and engaging activities for older people - how is this variety reflects upon a daily function of social workers, the focus group members noted that engaging activities for older people in social service institutions have time resources, e.g.: institutions that provide stationary service organise engagement activities every day, the clients are offered different activities, at the nursing hospitals engaging activities are organised 2 times per week $45 \mathrm{~min}$. each (more time is dedicated to health support but not to sociocultural/educational service provision). Informants listed the engaging activities: handicrafts, application, paper cutting, clay work, logical activities, 
reading (audio books, articles read out loud, fiction, news, novels, religious books).The focus group members mentioned that most clients have visionary impediments and reading out loud activities are popular.

The informants have noticed that older adults get tired after a short time, this situation has to be taken into consideration when organising sociocultural/educational activities. Another remark was that older adults are often passive, therefore, it is important to strengthen motivation for engaging them into activities.

When asked to list successful engaging activities for elderly clients, the informants stressed that singing folk songs, logical games, singing religious songs are activities related to the clients' past. In the informants' interpretation songs, religious singings are the activities that involve all the participants of the activity: some sing, others can listen. It is noticed that when working with the Alzheimer patients', folk song singing and listening affects them positively. It is important for the social workers to observe positive changes and positive emotions of the client. Through these activities the dynamics of regress is also observed when the client's recognition skill slows down.

In response to the question why do older adults choose activities they are familiar with and why do they learn something new, the informants answered that older people prefer activities which they are familiar with and have tried before in their lives since this gives them a sense of security. They are inclined not to trust new activities and are afraid to experiment. Therefore, when proposing new engaging activities social workers seek to strengthen clients' motivation to acquire new experience, to strengthen their trust in themselves and their capacities. It has been noticed that older people respond positively to routine activities and to repeating engaging activities. In the opinion of the informants their clients do not appreciate surprises but are satisfied with predictable things. In some cases it is difficult „to sell“ new activities for the individuals since they feel some sort of „loss of dignity“, in other instances the clients are keen on trying things out, so the situation varies in every separate case and is determined by a separate individual need.

Interviews with the focus group members revealed the fact that organising educational and engaging activities is part of social work but hospitals for the care of elderly allot less time and personnel resources than do social service institutions. Hospitals for the care of the elderly allot limited time because the character of work is dominated by filling out documents, mediating between doctors and client families and the engaging activities are arranged only for the special events.

The informants stressed the lack of social workers resources since in Lithuania there prevails an opinion that organising engaging activities is a part of social work. No professional appointments are planned for the organisers of engaging activities. The key obstacle in the informants' opinion is the attitude of the politicians that in dealing with the clients' needs the priority should be given 
to the physical care and medical care but not to the social care needs. Because of the shortage of the financing only the basic human needs are the key objective in the social care institutions, cutting the development of the engaging activities and the required personnel resources.

The research revealed that oftentimes practice with the older adults is not quite targeted and is difficult to define, the practice shows many attempts and experiments, and therefore, social workers are on the lookout for a good training course that would introduce a good gerontological practice. The informants indicated that there are no reports of methodical work in gerontology or the samples of the methods of work especially for the organisation of educational, engaging activities. This function often depends on the individual experimentation of social workers, creativity, learning from the experience of their colleagues, but mostly within the enclosed situation of one institution. Prevailing methodical material is written for the work with children but not with older adults.

Social care institution workers admitted that they receive strong support from their administration representatives. It is important to say that they do not feel separated from the administrative decisions; on the contrary, they feel rather involved and participating in decision taking processes.

\section{Conclusions}

Lithuanian Catalogue of Social Services which is instructional to social workers does not include educational activity as such but social workers provide their clients sociocultural services, which in their contents embrace educational activities such as organising pastime, engaging activities, individual and group activities with regard to the clients' needs. Social workers implement educational activities in relation to previous experiences and inclinations of the clients, they also look for new forms of educational activities, and they involve and motivate clients to take part in this quest.

Social workers consider it their function to organise older clients' pastime, their function embraces educational activities such as organising events, excursions, readings, singing, putting up exhibitions in practice. Social workers are motivated and interested and feel support of the administration; therefore, they are free and creative in organising educational engaging services for their clients, after assessing their needs, financial and personnel resources of the organisations. Educational engagement is an important part in the programme, a systemic feature of the social care institution's work.

\section{References}

Barbour, R. (2007). Doing Focus Groups. London: SAGE Publications.

Cernius, V. (2006). Žmogaus vystymosi kelias. Nuo vaikystès iki brandos. Kaunas: Pasaulio lietuvių centras. 
Gray, G. (2000). Culturally Responsive Teaching. Theory, Research and Practice. London \& New York: Teachers College Press.

Kuzmickienè, J. (2011). Rekreaciniu veiklu senyvo amžiaus žmonèms ypatumai. Magistro tezès. Vilnius: MRU.

Leliugiene, I. (2003). Socialine pedagogika. Kaunas: Technologija.

Lukamskiene, V., Budejiene, A. (2013). Socialinès paslaugos vyresnio amžiaus asmenims: savipagalbos ir socialinès globos aspektai. Gerontologija 14(4) (pp. 228-234). Vilnius: Lietuvos gerontologų ir geriatrų draugija.

Miezyte-Tijusiene, J., Bulotaite, L. (2012). Pensinio amžiaus žmonių socialinis aktyvumas bei psichologinè savijauta. Gerontologija 13 (4) (pp. 199-205). Vilnius: Lietuvos gerontologų ir geriatrų draugija.

Mikulioniene, S. (2011). Socialine gerontologija. Vilnius: MRU.

Sinkuniené, J. (2005). Laisvalaikio studijos ir rekreacijos administravimas. Socialinis darbas $n r .4$ (1) (pp. 122-130). Vilnius: MRU.

Socialines apsaugos ir darbo ministerija. (2006). Socialiniu paslaugu katalogas. Vilnius: Valstybès žinios, Nr. 31-1092.

Socialines apsaugos ir darbo ministerija. (2013). „Dél socialiniu paslaugu katalogo patvirtinimo" pakeitimo. Vilnius: Valstybès žinios, Nr. 74-3719.

Spierts, M. (2003). Balansavimas ir aktyvinimas. Metodiškai organizuotas sociokultūrinis darbas. Vilnius: VU Specialiosios psichologijos laboratorija.

Staniuleviciene, D. (2002). Veikla ir gyvenimo būdas. Veckiene N. (sudarytoja ir moksline redaktore.), Socialine gerontologija: ištakos ir perspektyvos (pp.194-203). Kaunas: VDU.

Statistikos departamentas. (2013). Globos istaigos seniems žmonéms. http://osp.stat.gov.lt/temines-lenteles15.

Van Manen, M. (2014). Phenomenology of practice. Meaning - Giving Methods in Phenomenological Research and Writing. California: Walnut Creek.

Zalimiene, L. (2003). Socialines paslaugos. Vilnius: VU Specialiosios psichologijos laboratorija.

Zemaitaityte, I. (2014). Empowerment of Older People to Participate in Educational Activities. SOCIETY, INTEGRATION, EDUCATION. Proceedings of the International Scientifical Conference, Volume II. (pp. 260-268). Rēzekne: Augstskola. 